Hershberg notes that Harvard in the end took a less stern position, which ex-President Conant supported. Whether it was right or wrong, Conant's initial view of resort to the Fifth Amendment was not a large matter in Harvard's overall struggle against McCarthyism.

It is a very long jump from this set of complaints to Hershberg's sweeping conclusion that on this front Conant "moved toward a subtle yet pernicious form of thought control". That is not the picture of Conant or his influence that those who were there remember, and neither Hershberg's own comments nor his footnote references give evidence supporting any such conclusion. The historian, once again, does not confirm the critic.

Diplomacy was not Conant's long suit. He failed conspicuously in wartime negotiations over nuclear cooperation with Britain, creating an impasse that was resolved only by Roosevelt, Churchill and Stimson. Nonetheless he very much wanted the appointment he won in 1953, leaving the Harvard presidency to succeed McCloy as the principal US representative in Germany, as High Commissioner and then as the first Ambassador. In these jobs, as Hershberg demonstrates, he was not so much unsuccessful as unnecessary. Dulles in Washington wanted no independent adviser in Bonn, and Adenauer recognized that he could do better by going directly to Dulles than by going through a man who did not know how to have no opinion of his own. Conant was neither the first nor the last ambassador to misunderstand the range of his role in the age of the airplane and telephone, but his appointment, and a later two years as a private citizen in Berlin, did allow him to play a significant personal part as an outstanding American who honoured the best of the German past, especially in science, and deeply believed in an honourable German future.

Finally, in his last round of public service, Conant became the leading advocate of reform in American public schooling. Here he made a mark exceptional in its force and clarity, but he would not be surprised that the American nonsystem has been resistant to his basic programme of reform: quality education for all children in public schools, to provide both equal opportunity and a fully demanding challenge to the young of all capabilities. Hershberg finds him farsighted in observing and describing the failure of public schooling in urban ghettos, but at first insensitive to the way black leaders would respond to his apparent acceptance of $d e$ facto segregation. Once again the analyst outran the diplomat. Conant's volumes on public education were nonetheless a major contribution, in yet another field, to understanding of a continuing American problem.

Conant was not an easy man to get close to, and it is not surprising that Hershberg has trouble understanding his family life. He tries hard, and Conant's family have tried to help him, both with family papers and with interviews. But the closer he gets to the man, the less certain his touch. The primary cause of the trouble is Conant himself; he was a genuinely reticent descendant of the Pilgrims. Yet the best guide here is not Hershberg's book but Conant's memoir, My Several Lives (underrated by Hershberg). Conant had an essentially wonderful marriage, for example, and that reality shows through in his own book. Hershberg offers more extensive evidence on family troubles, but except for the grievous illness of the older son it is mostly about difficulties of the kind that come sooner or later to most families. There is no matching emphasis on the integrity and intensity of a great marriage, old-fashioned in that the man's work came first, but old-fashioned also in his reliance on his wife, and in the way they made most large choices together.

Overall, this book is an impressive achievement. In the modern process of American academic appointment and promotion that Conant did so much to shape, nothing is more important than a young scholar's first major book. After Conant's time, I sat as a Harvard dean through dozens of presidential meetings in which such scholars and their books were considered, and I have found myself wondering how this book would fare before such a committee with Conant himself presiding. I think there would be criticism and perhaps even complaint from the chair, but Conant was an extraordinarily fair-minded man. He might well propose to disqualify himself, but I think such a proposal would not be in Hershberg's interest. I think that Conant would turn out to share my own strong opinion that on the evidence of this book the author has shown himself to be a historian of notable achievement and promise, and well qualified, as far as a single book can show it, to do with distinction the work that Conant himself may in the end have cared about most: the work of a permanent member of the faculty in a leading research university.

McGeorge Bundy is in the Carnegie Corporation of New York, 437 Madison Avenue, New York, New York 10022, USA.

\title{
Hearing the deeper harmonies
}

\section{Laura Garwin}

The Hidden Landscape: A Journey into the Geological Past. By Richard Fortey. Cape: 1993. Pp. 288. £19.99.

I HAVE never met Richard Fortey, but from his book I can think of no better companion for a walk through the British countryside. Stand with him on a bleak Yorkshire moor and be transported to a lush rain forest of 100 million years before; gaze across the low, rounded hills of northwest Scotland and recognize a landscape inherited from the Precambrian; look down on the waters of the English Lake District and see reflections of a glacier that vanished 7,000 years ago. But these links between past times and present landscapes are just the start, for Fortey's mission is to show us that the influence of the rocks beneath our feet extends far beyond scenery - to flora and fauna, agriculture and architecture, and beyond, into our daily lives.

The 'hidden landscape' of the book's title has several different meanings, the most straightforward of which refers to the fact that the bedrock geology of the British Isles (and indeed of most parts of the world) lies hidden beneath a blanket of soil and vegetation. Fortey imagines himself "rolling back this skin, as one might a carpet, to reveal the rocks beneath". Applying this process to the British Isles reveals an extraordinary variety packed into a small space: sedimentary, igneous and metamorphic rocks, and representatives of each of the geological periods. This richness of geology is one way in which the book avoids being too parochial. The other is Fortey's approach: by travelling chronologically upwards through the geological column, rather than geographically around the British Isles, he can tell us something of the history of life on Earth, and of the wandering continents, along the way.

In fact, Fortey packs a lot of modern Earth science into the book - including the story of the vanished ocean of Iapetus, which separated northern from southern Britain until it closed about 400 million years ago, leaving only the Solway Firth, the sediments of the Southern Uplands, and some otherwise very confusing fossils to bear witness to its former existence. We also learn about radiometric dating, experimental petrology and even the early Solar System. But while these forays into geological science undoubtedly enrich the broth, Fortey's greatest delight lies in revealing the connections between geology and our everyday experience of the natural world.

And well might he delight, for the connections are many and multifarious. At the broadest, most familiar scale, we see how the Highland Boundary Fault creates a sharp transition between the comfortable farmlands of the Midland 
Valley of Scotland, which overlie sedimentary rocks, and the wild highlands to the north, betraying the presence of tougher metamorphic rocks beneath. But Fortey tells us, too, about the plants that flourish on the nutrient-poor moors of the highlands: for example, the berries of the heath family (Ericaceae), which spark a paragraph's digression about the problem of obtaining vitamin $\mathrm{C}$ in high-latitude regions. Other highland plants prompt reflections on the survival of primitive forms in harsh conditions (the clubmosses on today's moors trace their heritage back to Carboniferous coal swamps) and the stranding of Arctic flora on British peaks as the glaciers retreated.

From flora, on to fauna: as the heather follows the geology, so does the grouse. Why are brown trout found in the streams of both Derbyshire and Hampshire? Because both regions are underlain by limestone - respectively, Carboniferous and Cretaceous (the famous Chalk). Nor are humans impervious to the influence of the hidden landscape. Fortey goes beyond the obvious examples of agriculture (dictated by the fertility of the soil, itself controlled by the bedrock) and mining, to argue that much of today's human geography still reflects the geological imperative. The vales floored by Permian and Triassic rocks are "natural corridors for traffic and trade"; hence one finds canals along them, and also ancient towns. The wool towns of western and middle England grew up near the outcrop of the Fuller's Earth - a Jurassic deposit rich in the clay mineral montmorillonite, which can be used to clean wool of its natural grease. The modern chemical company ICI owes its location, argues Fortey, to the outcrop of Permo-Triassic salt.

To appreciate many of Fortey's examples, one needs to be fairly familiar with British geography. Instead of having the geological map of Britain and Ireland reproduced twice, could we not have had a topographic map, to aid readers who would not otherwise know what it means for a rock formation to extend "from Nottingham to Sunderland, with its widest outcrop at the coast north of Hartlepool"? More generally, one often gets the feeling that Fortey is writing for a British audience - which is a shame, as this is emphatically not just a book about the geology of the British Isles; it is about how an appreciation of geology and its hidden connections can enrich one's experience of life in exactly the same way as can an understanding of art or music. To quote one of Fortey's more whimsical examples, does it not deepen the enjoyment of a whisky and mineral water to notice that although one ingredient is Scottish and the other English, they both originate in rocks of the Precambrian era?

But the ability to recognize harmony necessarily brings with it a sensitivity to discord. The flip side of the pleasure provided by vernacular architecture buildings made from local stone, "at ease with [their] geological foundations" - is the pain brought on when the connections are ignored. In this regard, Fortey is perhaps an extreme geological aesthete: he rails, not just against the brightly coloured petrol station which we might all recognize as a modern synthetic abomination (although he adds that it does not even have the modesty to clothe itself in lichens, as the local stone does), but against the embarrassment of houses made of Jurassic Bath stone sitting on the Cretaceous chalklands. One feels for him, as for the person whose hyper-perfect pitch ruins the enjoyment of an average concert; but even those of us with more normal sensibilities will acknowledge the loss entailed in the march of uniform brick and slate across what was a richly varied landscape.

Fortey's stated aim is to "inspire a way of looking at the landscape". Read this book and you will never see the world around you in quite the same way again.

Laura Garwin is Physical Sciences Editor of Nature.

\section{Technopolis}

\section{HenryPetroski}

A Scientist in the City. By James Trefil. Doubleday: 1994. Pp. 266. \$23.95.

AMONG the fundamental differences between scientists and engineers are their generally divergent objectives. The purest scientists observe and study the given world only to understand and explain it and its phenomena; the purest engineers want to manipulate the parts and processes of the given and found world into artefacts of benefit to mankind. Scientists analyse; engineers synthesize. The products of science thus tend to be words and theories; the products of engineers are plans and things.

In his latest book, the scientist-writer James Trefil turns his analytical eye to the quintessential products of synthesis cities and their artefacts. As with much science, his musings begin in wonder, specifically atop the Sears Tower looking down at Chicago, and he progresses from wondering about what problems had to be solved to build the world's tallest building to wondering "what else in the city depended in a similar way on our basic understanding of science and nature".

Allowing Trefil the simplistic conventional wisdom that engineering and technological advances are little more than applied science, the premise of his book is an excellent one, and even an engineer might sympathize with the popular goal of wanting the reader to see modern cities as "products of a series of discoveries of the physical universe". Trefil proposes in his introduction to accomplish this objective by looking at three discoveries: "the ability to manipulate atoms"; "the ability to unlock stored energy"; and "the ability to store and transmit information electrically". But the reader might be advised to keep in mind that each of these discoveries or accomplishments is in fact a feat of engineering that may or may not involve science in the usual sense. Indeed, manipulating atoms over fire, perhaps one of the essential hallmarks of civilization, required neither formal science nor engineering, although the craft may have been honed by the rudiments of their methods.

Despite oversimplifications of fundamentals, which are understandably made in the interest of getting on with the story, the book is a good read. Trefil tells interesting tales about the development of such materials as the glass and steel that go into modern skyscrapers, and he explains well the problems associated with moving things such as people, water and waste in very tall buildings. The first half deals with the city of today, and with Trefil's personal encounters among the systems of several specific cities; the second half of the book deals with the city of the future. Amid discussions of the implications of life among very tall buildings and the nature of suburbs, Trefil covers a lot of ground, sometimes as fast as the Magiev trains that he describes as redefining the distances commuters of the future will tolerate, in the rare time they might have to leave the information highway at home and travel to the office.

In the end, the success of science and engineering, and of books on them, rests in the details. Trefil assures the reader that "engineers, you know, are a gloomy lot, always dwelling on what can go wrong with their systems", but he neglects to remind us that by "dwelling on what can go wrong", engineers are striving to get it right so their products can be relied on by those who are not engineers. Who wants engineers to be so sanguine about an elevated walkway that they leave the design details to the construction workers?

Although Trefil is not an engineer, he might have been a bit more critical of some of the details on which his own construction rests. For example, what he says engineers call "shear loads" they might hardly recognize. Steel reinforcing rods do not provide strength directly against shear, as Trefil states on page 36 , but against tension, in which concrete is weak. The illustrations in the book can be equally wrong. The figure purporting to show the "flow of force on a lintel", for example, has the lintel between the posts rather than resting on top of them. The 